and helping to "diffuse" new technology. Thus the concept appears to be of an intellectually and politically sophisticated institution to assist the country's technological development: one which will be able to help industry to make its forecasts and plans, but will, at the same time, take into account likely social impacts and obstacles. CATSS's first programmes begin next month - training programmes in biotechnology and microelectronics. A director for the centre is expected to be appointed before the summer.

Robert Walgate

\section{Fluoridation in Scotland}

\section{Days in court}

A legal trial that will decide whether Strathclyde Regional Council becomes the first Scottish water authority to add fluoride to its water supply has now passed its 130 th day, making the record books as the longest ever court case to be heard in Scotland. The Edinburgh Court of Session, Scotland's High Court, has become a battleground for fluoridation and anti-fluoridation interests.

The case, McColl v. Strathclyde Regional Council, opened on 23 September 1980 , and was originally expected to last twelve weeks. The eventual cost is estimated at $£ 1$ million, which would make it the most expensive civil case in Scottish legal history. The costs of Strathclyde Regional Council will be met by its four area health boards. The expense of an expert witness can be as much as $£ 450$ a day and many have come from as far away as the United States and Australia. If the case lasts for 150 days, as it may well do, lawyers' costs alone could exceed $£ 60,000$.

The issue at stake is twofold - the legal right of the council to add a trace of fluoride to the water supply and the medical effects of fluoride. In 1977, the council voted by a majority of 43 to 42 to build a $£ 2$ million plant to introduce fluoride into the water supply. Mrs Catherine McColl is contesting the decision, claiming the right of herself and her grandchildren to drink unfluoridated water on the grounds that fluoride is not only useless but can cause cancer and other diseases. The hearing is before Lord Jauncey.

The evidence has been intricate and technical. Mrs McColl appeared in the box only on the first day. The medical issues have focused on the contention that fluoride can cause cancer. Sir Richard Doll for example, has so far given evidence for two weeks. It is expected that Lord Jauncey will take months to reach a judgement.

Evidence against fluoridation has been given by Dr John Yiamouyiannis, formerly of the National Health Federation organization and a member of the US National Health Action Committee, and Dr Dean Burk, a retired National Cancer Institute laboratory scientist. In some ways the
Scottish trial is a re-run of the hearing in West View, Pennsylvania in November 1978, when Drs Yiamouyiannis and Burk also argued that there is a link between fluoride and increased cancer mortality rate. Dr Burk has separately told the US House of Representatives that fluoridation is "socially imposed murder".

In Pennsylvania, Judge Flaherty, then a lower court judge, issued an injunction ordering West View Water Authority to cease water fluoridation. His decision, however, was appealed against on grounds of jurisdiction. In January 1979, after a review of the evidence by the Department of Environmental Resources, the water authority was ordered to continue to fluoridate. The Minnesota Governor's Commission, appointed in 1978 to study the health effects of water fluoridation, examined the same body of evidence as Judge Flaherty and concluded that "an association between fluoridation and cancer has not yet been shown".

Fluoride has been added to water supplies in Britain since 1957, and 10 per cent of the population drinks artificially fluoridated water (in the United States 44 per cent of the population drinks treated water). The 1972 Water Act enjoins the water authorities to provide "wholesome water', but although 87 out of 90 area health authorities are in favour of fluoridation, in the past 7 years few schemes have been implemented. The water authorities seem reluctant to proceed in the absence of parliamentary legislation.

The decision in Scotland could thus be influential, particularly as a similar case is being prepared in Calderdale, Yorkshire. If Lord Jauncey decides in favour of Strathclyde, the issue of further legal aid for an appeal will arise. If the case goes to the House of Lords, it may take several years for a final decision. And neither side may be able to claim a victory - if, for example, the judgement is that fluoride is beneficial to dental health but that water authorities do not have full jurisdiction to determine what goes into the water supply.

In Strathclyde, the irony is that local elections early this year could render any judgement nugatory: a new council could vote to reverse the fluoridation policy.

Jane Wynn

\section{Rubik's cube \\ Puzzles galore}

A decision is expected this week from the British high court hearing of a copyright and passing-off suit brought by the Politehnika Industrial Corporation of Budapest, manufacturers of the original Rubik's cube, against Dallas Print Transfers of London, importers of an alleged copy known as the "Wonderful Puzzler", produced in Taiwan.

The case, initiated by an injunction from Politehnika last March, has turned on two main issues. As far as copyright is con- cerned, the emphasis has been on the internal structure of the cube, involving comparison of production blueprints, while the passing-off charge is based on claims that the puzzler has on occasion been marketed as the Rubik cube.

The dual nature of the case corresponds appropriately to Dr Erno Rubik's own dual interest in the cube - structure and concept. A lecturer in architecture at the Budapest Academy of Applied Arts, he was, he says, originally interested primarily

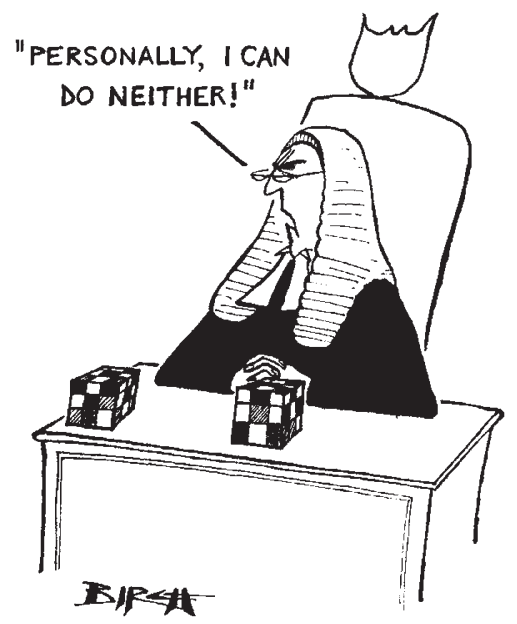

in the internal mechanism of the cube which allows each face, consisting of a $3 \times$ 3 array of cubelets, freely to rotate either clockwise or anticlockwise. Only later did he decide to communicate his pleasure in the new device to others by offering it for commercial construction.

Rubik says that other international contributions to the booming market in logic toys - pyramids, spheres and the like embody essentially the same principle as the cube, since the various sections are displaced without changing the over-all shape of the assemblage. The one major exception, known as the "tower", which exists in two contending Hungarian versions, is, in his opinion, simply the old " 15 puzzle" invented in the 1880 s, rolled up into cylindrical form, since it incorporates a vacant parking spot into which an element can be moved during the transfer process.

The popularity of the cube, which Rubik himself cannot adequately explain, has made him reputedly the seventh richest man in Hungary and won for him a "Gold Medal of Labour" for his services to Hungarian industry, and has had a number of unexpected spin-offs. The possible and impossible configurations of the cube, Rubik said last December, were attracting attention from physicists as a means of modelling the properties of quarks.

In Hungary, the unprecedented boom in the toy industry generated by the cube has highlighted a number of defects in the New Economic Mechanism, and seems to have been in part responsible for the recent relaxation of the rules governing small enterprises. 